\title{
WAT IS VIRTUEEL GEHEUGEN CONCEPTIE?
}

\author{
door W. F. H. Alleijn/H. J. Lijnes
}

\section{Algemeen}

Wanneer $U$ over automatisering leest dan komt $U$ thans veelvuldig de woorden ,,virtuele techniek" en ,virtueel geheugen conceptie” tegen. Dit artikel wil een poging zijn om wat duidelijkheid te verschaffen. Bewust schrijven wij een poging, aangezien het in de praktijk gebleken is dat er voortreffelijke boeken en artikelen zijn verschenen voor de insider - die dus reeds zeer veel weet van de software- en hardware-aspecten bij de toepassing van computersystemen - maar ons is nog geen literatuur bekend waarin is getracht op een eenvoudiger wijze tot een verklaring van de onderhavige begrippen te komen.

Een handwoordenboek geeft als verklaring voor „,virtueel": innerlijk aanwezig, maar voor het ogenblik niet werkzaam. Vrij vertaald: er is iets beschikbaar maar het behoeft of wordt (nog) niet gebruikt. Welnu dit slaat in dit kader op de beschikbaarheid van programmadelen in een opslaggeheugen van een computersysteem die niet of nog niet worden gebruikt, maar wel snel kunnen worden overgebracht naar het werkgeheugen om voor de verwerking van gegevens te worden gehanteerd.

Alhoewel een vergelijking veelal ergens mank gaat, stellen wij $U$ voor een bezoek te brengen aan een winkel met een daaraan verbonden magazijn. Het assortiment artikelen is seizoengevoelig. Om snel te kunnen werken, zullen in de verkoopruimte die artikelgroepen aanwezig moeten zijn, waarnaar in een bepaald seizoen de meeste vraag bestaat, dan wel binnenkort te verwachten is. In het magazijn zullen alle artikelgroepen zijn opgeslagen.

Regelmatig zal aanpassing van de winkelvoorraad nodig zijn.

Indien wij nu naar een computersysteem gaan, dan vergelijken wij de winkel met het werkgeheugen en het magazijn met het opslaggeheugen en de programma's met artikelgroepen.

De programma's of delen daarvan die worden gehanteerd dan wel waarvan bekend is dat zij binnenkort moeten worden gebruikt, dienen in het werkgeheugen beschikbaar te zijn. De programma's of delen daarvan die niet worden gebruikt en eerst later zullen worden toegepast, zijn opgeslagen in het externe geheugen, maar zijn wel (snel) bereikbaar. Hierbij moet worden aangetekend dat de ontwikkeling van de technologie ertoe heeft geleid dat de interne snelheid van computersystemen aanmerkelijk is toegenomen en dat de opslag van programmatuur tegen aanvaardbare kosten is te verwezenlijken.

Snelheid en kosten zijn de componenten die de nieuwe technieken mogelijk maken. Wel blijft bestaan dat het vastleggen van gegevens c.q. programmatuur in het snellere werkgeheugen relatief kostbaarder blijft dan die in het "tragere" opslaggeheugen.

Het meest eenvoudige, maar ook het snelste zou gewerkt kunnen worden met een vrijwel onbeperkt werkgeheugen, maar dit is op economische gronden (nog) niet haalbaar. 


\section{On twikkeling computers}

Indien wij de ontwikkeling van de eerste computers tot de huidige computersystemen volgen dan werden en worden de doelmatigheid van de toepassing en de kostenaspecten in belangrijke mate bepaald door de snelheid en de omvang van het werkgeheugen alsmede die van de opslaggeheugens.

Aanvankelijk beschikte de computer over invoerapparatuur om een programma vastgelegd in ponskaarten of in een ponsband in te lezen. Het ging daarbij om één programma dat in het werkgeheugen werd gebracht. Vervolgens werden de gegevens ingevoerd, eveneens via een van de genoemde invoermedia. De verwerking geschiedde batch-gewijs en de gewenste informatie werd uitgevoerd in de vorm van de ponskaart of de ponsband dan wel via een aan de computer gekoppeld drukwerk(printer).

Van vaste gekoppelde opslaggeheugens met een beperkte capaciteit en trage snelheid werd al spoedig gebruik gemaakt in de vorm van de trommelgeheugens. Indien met de verkregen uitvoer verder moest worden gewerkt of met een ander programma moest worden gestart, dan diende eerst het daartoe vereiste programma te worden geladen. Het oorspronkelijke programma werd in het werkgeheugen overschreven en het volgende programma nam de plaats in. Veelal werd het opslaggeheugen op "nul" gesteld om vervolgens opnieuw te worden geladen met de benodigde bestanden, tabellen e.d.

Verwerking van één programma tegelijk met een beperkt aantal gegevens en beperkte verwerkingsmogelijkheden.

\section{"Overlay"-techniek}

Wanneer een programma werd samengesteld en het bleek de capaciteit van het werkgeheugen te overschrijden dan waren de mogelijkheden voor de programmeur:

- trachten het programma zodanig aan te passen door weglating van bepaalde functies en/of verkleining van invoer- en uitvoergebieden en/of werkgebieden dat het binnen de gegeven geheugenomvang een plaats kon vinden;

- gebruik maken van een ,overlay"-techniek.

$\mathrm{Bij}$ het gebruik van een overlay-techniek wordt een programma gesplitst in delen, bijvoorbeeld:
A. een deel voor initialiserende werkzaamheden,
B. een deel dat de eigenlijke verwerking verzorgt en
C. een deel dat de afsluitende werkzaamheden uitvoert.

De verwerking vindt dan als volgt plaats:

- deel A van het programma wordt in het werkgeheugen geplaatst en daarmede word het initialiserende werk uitgevoerd;

- vervolgens wordt deel B geladen, waarmede deel A geheel of gedeeltelijk wordt overschreven (bedekt/,overlayed"), waarna de verwerking kan plaatsvinden;

- tenslotte wordt deel C ingelezen waarbij deel B op zijn beurt geheel of gedeeltelijk wordt overschreven, waarna de afsluitende werkzaamheden kunnen worden uitgevoerd. 
De overlay-techniek wordt reeds vele jaren toegepast en biedt de mogelijkheid om met een klein systeem grote programma's in fasen uit te voeren.

De volgende schets geeft een beeld van de inhoud van het werkgeheugen in de onderscheiden verwerkingsfasen:

werkgeheugen

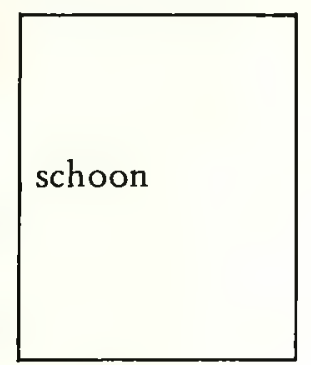

fase 1

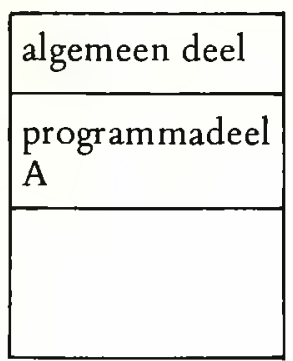

2

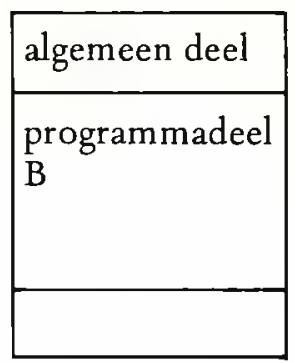

3

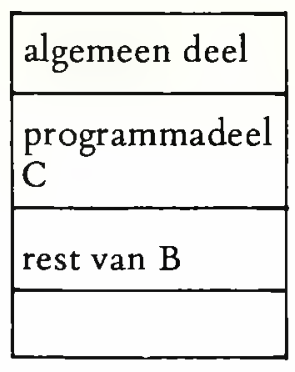

4

$\mathrm{Bij}$ de overlay-techniek wordt soms binnen één programmadoorloop van programmadelen gewisseld.

Begonnen wordt met deel A, waarbij de verder benodigde gegevens worden vastgehouden. Vervolgens wordt deel B in het geheugen gebracht, deel A geheel of gedeeltelijk overschrijvend. Nu wordt het programma verder afgewerkt. Nadat de uitvoer is verkregen, bijvoorbeeld door het afdrukken van een of meer regels, wordt deel A weer naar het werkgeheugen gebracht, enzovoorts.

Het zal geen toelichting behoeven dat door deze wijze van werken de af te drukken regels belangrijk trager doorkomen dan de snelheid van de printer zou toelaten. Om met de geschetste overlay-techniek te kunnen werken, dient bij het programma-ontwerp hiermede rekening te worden gehouden. De uitwerking dient namelijk door middel van de applicatie-programmatuur te worden gerealiseerd.

\section{Virtuele techniek}

Met deze kennis gewapend gaan wij nu naar de virtuele techniek. De virtuele techniek vormt als het ware een verfijnde overlay-techniek die mede het voordeel biedt dat deze door een combinatie van hard- en software automatisch wordt gerealiseerd.

Reeds in het begin van de zestiger jaren paste „Ferranti” in de Atlascomputer het principe van de virtuele techniek toe. Daartoe werden de programma's verdeeld in delen of blokken van een vaste omvang. Voornamelijk als een soort uitbreidingsmechanisme voor een relatief klein werkgeheugen kwam op deze wijze meer ruimte voor de programmatuur binnen de computer beschikbaar dan het werkgeheugen kon bevatten.

Ook „Burroughs" paste in de computer 5000 als een van de eersten een virtueel geheugen toe. Hierbij werd echter het geheugen verdeeld in blokken van een variabele omvang. De programmadelen van een vaste omvang worden 
over het algemeen „pagina's" (pages) genoemd en de geheugenblokken met een variabele grootte worden met ,segmenten" aangeduid.

De computersystemen nemen in omvang en samenstelling toe, waarbij komt dat meerdere programma's (multiprogramming) ,tegelijk” worden verwerkt (in wezen volgtijdig!). Hierbij komt dat lopende programma's moeten worden onderbroken (interrupts) om voorrang te geven aan programma's met een hogere prioriteit.

Als gevolg van de ontwikkeling van de datatransmissie en teleprocessing vinden koppelingen met stations (terminals) op afstand plaats. Hierdoor nam de wens naar een directe beschikbaarheid maar mede een snelle bereikbaarheid van programmatuur zowel in omvang als verscheidenheid zeer sterk toe. Het streven is er dan ook op gericht om zoveel mogelijk programmatuur binnen de computer op te slaan. Hierbij moet worden aangetekend dat incidenteel gehanteerde dan wel laag frequent gebruikte programma's alleen op te stellen tijdstippen ,geladen" zullen worden.

Het werkgeheugen van een computer met een virtueel-geheugen-conceptie is verdeeld in adresseerbare "page-frames" van een vaste lengte (mogelijk te vertalen door pagina-kaders). De programmeur maakt bij de samenstelling van zijn programma's onveranderd gebruik van symbolische adressen.

Het assembleer- dan wel het compileer-programma verzorgt de adrestoewijzing - ook virtueel - binnen het werkgeheugen. Tevens wordt het programma automatisch verdeeld (geknipt) in pagina's met dezelfde lengte als een paginakader. Deze pagina's vinden hun plaats in het opslaggeheugen.

Wanneer nu een of meer pagina's nodig zijn voor enige verwerking, komen als eerste vragen: „zijn de benodigde pagina's reeds in het werkgeheugen aanwezig en zo ja, waar zijn deze bereikbaar?" In de centrale verwerkingseenheid is een adressenruimte waarin een tabel wordt bijgehouden, waarin dit kan worden nagegaan. Indien de vereiste pagina's niet of niet alle in het werkgeheugen zijn opgenomen volgen de vragen: „welke pagina of pagina's moeten vanuit het opslaggeheugen worden overgebracht naar het werkgeheugen en welke paginakaders zijn daartoe beschikbaar? "Wanneer geen paginakaders beschikbaar zijn, moet worden vastgesteld welke vrijgemaakt (overschreven) kunnen worden met de vereiste pagina's. Vervolgens worden de „vrijgegeven" paginakaders met de vereiste pagina's geladen.

Hierbij moet worden aangetekend dat de volgorde van de pagina's niet aaneensluitend behoeft te zijn. Dit in tegenstelling tot de eerder geschetste overlay-techniek, waarbij de programmadelen chronologisch aansluitend moeten worden opgenomen. Er is hiermede geen statische maar een dynamische allocatie verkregen.

De vertaling van het virtuele adres naar het reële adres vindt plaats op het moment van gebruik, tijdens de uitvoering van het programma. Bij de vertaling wordt gebruik gemaakt van een adresvertalingsmechanisme dat bestaat uit een combinatie van hard- en software. Het software-deel is een tabel waarin de pagina's en de bijbehorende paginakaders zijn vermeld.

De tabel van de pagina's en paginakaders wordt continu aangepast aan de zich wijzigende omstandigheden. Wanneer een bepaalde pagina moet worden gehanteerd, wordt op deze wijze het desbetreffende reële adres snel gevonden. 
Hierbij dient te worden opgemerkt dat de mogelijkheid bestaat dat tijdens de verwerking wijzigingen in bepaalde pagina's worden aangebracht. Indien deze ook bij verder gebruik gehandhaafd moeten worden, dient de desbetreffende pagina, na gebruik, te worden teruggeschreven naar het opslaggeheugen. Indien geen wijziging heeft plaatsgevonden behoett de pagina niet te worden teruggeschreven. De virtuele systeemprogrammatuur regelt dit automatisch. In het opslaggeheugen blijft de pagina volledig behouden ook na overdracht naar het werkgeheugen.

Buiten het voordeel van het vermelde automatisme dient als voordeel van de virtuele techniek te worden vermeld dat het verplaatsen van pagina's - die veel kleiner zijn dan de oorspronkelijk gehanteerde programmadelen - hierdoor snel kan gebeuren. De overdracht van pagina's blijft echter tijd kosten.

Men krijgt nu eenmaal niets voor niets. Indien de applicatieprogramma's slecht zijn gestructureerd kan dit zelfs leiden tot aanzienlijke vertragingen in de programma-uitvoering.

Wij noemden reeds dat de pagina's van één programma niet aaneensluitend in het werkgeheugen behoeven te worden opgenomen, maar daarin zeer verspreid kunnen en mogen staan. In een schets zullen wij $U$ nu een voorbeeld geven hoe de indeling van een werkgeheugen op verschillende tijdstippen kan zijn.

Op de verticale lijn zijn de paginakaders in streepjes aangegeven, terwijl de programma's en pagina's daarvan met letters resp. cijfers zijn vermeld. De cijfers langs de verticale lijn geven het aantal paginakaders aan.

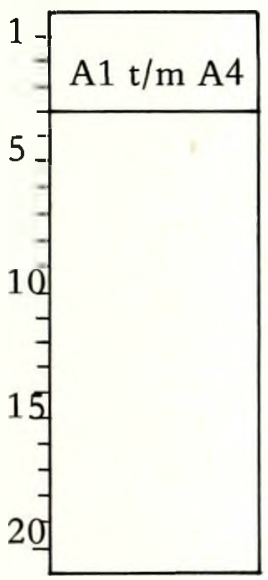

(1)

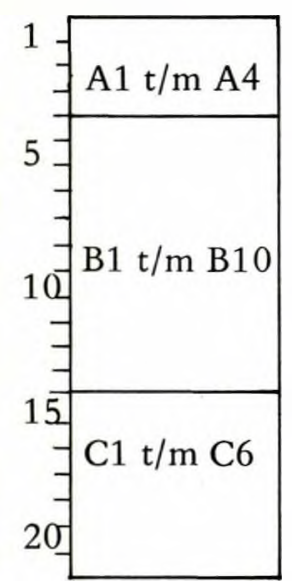

(2)

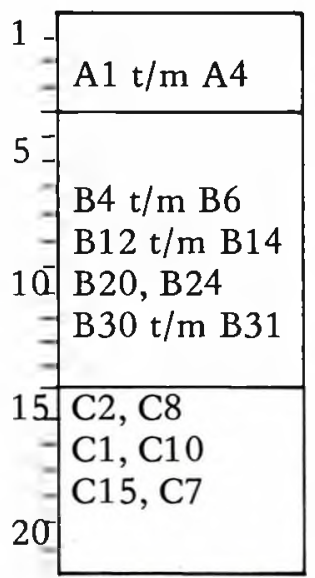

(3)

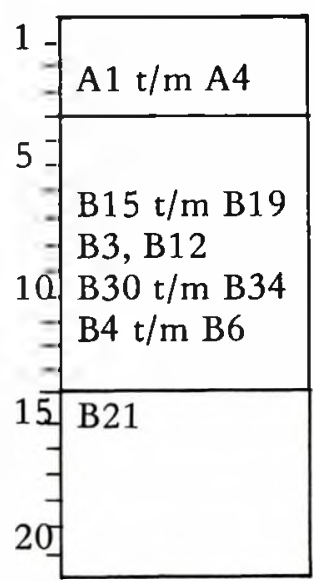

(4)

(1) Programma A (supervisor) in het werkgeheugen; de rest van het werkgeheugen vrij.

(2) Startsituatie met programma B en C in het werkgeheugen.

(3) Programma B en C tijdens de uitvoering.

(4) Programma C gereed; de daardoor vrijgekomen ruimte in het werkgeheugen wordt in beslag genomen door programma $\mathrm{B}$.

Diverse computerleveranciers brengen apparatuur op de markt die gebaseerd $m a b$ blz. 272 
is op de virtueel geheugen conceptie en vele zullen volgen.

Alhoewel wij geen limitatieve opsomming pretenderen, noemen wij enige leveranciers: Burroughs, IBM, Unidata, Honeywell-Bull.

De virtuele techniek is zeker niet nieuw te noemen, maar de technische mogelijkheden van vandaag en morgen maken een verdergaande inschakeling van de computer in zijn eigen huishouding zodanig dat we hiermede meer en meer geconfronteerd zullen worden.

Het is daarom gewenst dat de gebruiker deze ontwikkelingen kritisch volgt. Hij zal daardoor beter in staat zijn zelf te bepalen wat goed voor hem is.

Voor de lezer die zich verdergaand wil verdiepen in de virtueel geheugen conceptie, noemen wij onder meer:

1 De virtueel geheugen conceptie. Brochure IBM reg.nr. G514-5088-00.

2 Virtual storage and virtual machine concepts. IBM Systems Journal nr. 2, 1972.

3 Virtual Memory by Peter J. Denning. Computing Surveys, September 1970.

4 Virtual Storage - an introduction, survey and audit appraisal. EDPACS September 1973.

5 Toepassingsmogelijkheden van virtuele technieken, lezing van Ir. M. van Zutphen voor leden van het Genootschap voor Automatisering. 